\title{
A Magic Thread / Um Fio Mágico
}

by

Eduardo Nunes Jansen

A supporting thesis paper in partial fulfillment of the

Master of Fine Arts degree in Documentary Media

Yeates School of Graduate Studies

Ryerson University

(C) Eduardo Nunes Jansen

2017 

TABLE OF CONTENTS

$\begin{array}{ll}\text { AUTHOR'S DECLARATION } & 04\end{array}$

$\begin{array}{ll}\text { ABSTRACT } & 05\end{array}$

$\begin{array}{ll}\text { ACKNOWLEDGMENTS } & 06\end{array}$

$\begin{array}{ll}\text { PROLOGUE } & 07\end{array}$

CONTEXT

Family History in the Context of National History 11

$\begin{array}{lr}\text { Memory and Silence } & 12\end{array}$

Military Dictatorship and the Erasure of Memory 13

Hierarchy and Social Structure in Brazil $\quad 15$

Being Queer in Brazil $\quad 23$

A Personal Search for Identity $\quad 26$

DOCUMENTARY RELEVANCE

The Challenges of Telling my Own Story 29

Creating Spaces through Documentary Practice 30

METHODOLOGY

How the Film was Born $\quad 37$

$\begin{array}{ll}\text { The Feminine Element } & 38\end{array}$

$\begin{array}{ll}\text { Performance } & 39\end{array}$

CONCLUSION 45

$\begin{array}{ll}\text { BIBLIOGRAPHY } & 47\end{array}$ 


\section{AUTHOR'S DECLARATION}

I hereby declare that I am the sole author of this Masters Research Paper. This is a true copy of the Masters Research Paper, including any required final revisions.

I authorize Ryerson University to lend this Masters Research Paper to other institutions or individuals for the purpose of scholarly research.

I further authorize Ryerson University to reproduce this Master Research Paper by photocopying or by other means, in total or in part, at the request of other institutions or individuals for the purpose of scholarly research.

I understand that my Masters Research Paper may be made electronically available to the public.

Eduardo Nunes Jansen 


\section{ABSTRACT}

This thesis paper is written in support of my short documentary film Um Fio Mágico / A Magic Thread which combines different familial and historical narratives. In order to better understand the possibilities of living openly as a queer individual and to gain a stronger sense of my ancestral history, this thesis explores the parallels between the journeys of my ancestors and the contemporary journeys of my family members and myself. The struggles that women in my family have endured in a patriarchal society, for example, and my own search for freedom and happiness are mirrored in the historical struggles that women, black, queer, and Indigenous people endured in colonial Brazil. The paper interrogates the impact of that historical context on the evolution and migration of my family. It also explores various expressions of the feminine, both in the context of the country's delayed feminist liberation and the emergence of dynamic queer and trans identities in Brazil. 


\section{ACKNOWLEDGMENTS}

I would like to express my gratitude to the faculty and administrative personnel of the School of Image Arts at Ryerson University as well as my colleagues and personal friends who offered continuous support, feedback and great inspiration throughout the journey of making my film.

Amongst these great individuals, a few names must be highlighted for their constant support, magnificent inspiration, professionalism and for their amazing generosity as human beings. I am very grateful to my supervisor, Gerda Cammaer, and my advisor, Pierre Tremblay, for always being there for me. I appreciate very much the support of the director of the Documentary Media Program, Katy McCormick. Many thanks also to Alison MacLeod, our fantastic graduate program administrator. My deepest gratitude to my colleague and friend, Peter Conrad, without whom this journey and work would not have been this rewarding.

A very special thank you to all the people who helped me tell my story, especially my subjects Maria Gecília Nunes Jansen, Biatriz Bezerra da Silva, Hélio Jansen, Pedro Nunes Filho, Juliana Bezerra da Silva and Dagmar Siqueira. Isabela Nunes Jansen Vasconcelos helped me immensely with the Portuguese language and many story-telling elements. The generosity and love of my friends and family in Brazil guide me and give me strength every day.

This film and work are dedicated to the magnificent women in my life, and to my uncle and godfather Pedro Nunes Filho (in memoriam) whom I lost during the post-production of my documentary.

Meu querido Pedro, você está sempre comigo, inspirando-me, guiando-me e, como de costume, abrindo portas e caminhos. Muito obrigado por tanto amor. 


\section{PROLOGUE}

I was born and raised in Brazil, a vast country with a rich, complex past, and a present even more difficult to understand. In order to start telling the story that unfolds in my film, I needed to revisit important facts of the history of Brazil so that I could find the many missing pieces of my own family’s history puzzle.

As a child at school, I heard numerous times that Brazil was "discovered" by the Portuguese in the year 1500. That was the first official time some white European men set foot in the country and started exploring its riches. ${ }^{1}$ Brazilian musician Chico Buarque wrote: Não existe pecado do lado de baixo do Equador. ${ }^{2}$ Although Portugal and its royal family were Catholic, that seemed to be the mentality of the supposedly "white catholic" Portuguese fleet when they arrived in Brazil in 1500 representing the crown of Portugal and its interests: there's no such thing as sin below the Equator line. ${ }^{3}$ Since Brazil was discovered in the year 1500, a lot of historical facts and truths seem to have been covered with a thick, dark veil of silence. Opposite to what some may believe, censorship in Brazil did not start with the military dictatorship following the 1964 coup that overthrew the democratic government in place. ${ }^{4}$ It started when the Europeans set foot in Brazil. At that time, the white men started exploring, conquering, raping the wild coast and

${ }^{1}$ Richard A. Gordon, "Recreating Caminha: the Earnest Adaptation of Brazil's Letter of Discovery in Humberto Mauro's 'Descobrimento do Brasil (1937)," in Hispanic Issue, (Vol. 120, n.2, Baltimore: The John Hopkins University Press, 2005), 408-409.

${ }^{2}$ Chico Buarque de Holanda and Ruy Guerra, Sin does not exist past the lower part of the Equator line "Não Existe Pecado ao Sul do Equador," in Chico Canta, (Rio de Janeiro: Phonogram/Philips, 1973). Translation in English by Eduardo Nunes Jansen.

${ }^{3}$ Bailey W. Diffie and George D. Winius, "Foundations of the Portuguese Empire - 1415-1580," in Europe and the World in the Age of Expansion, Volume 1, edited by Boyd G. Shafer, (Minneapolis: University of Minnesota Press, 1977), 189-190.

${ }^{4}$ Maurício Lissovsky and Ana Lígia Leite e Aguiar, "The Brazilian Dictatorship and the Battle of Images," in Sage Journals, (Vol. 8, Issue 1, October 8, 2014), http://journals.sagepub.com/doi/abs/ $10.1177 / 1750698014552404$. 
killing the indigenous people in a variety of ways. The Portuguese also developed in Brazil a colonial structure creating a massive slave labour force. The relationship between the white European men, the Brazilian indigenous peoples and the slaves brought to Brazil from Africa in large numbers during the colonial period shaped the identity of the colony and the Brazilian people. $^{5}$

In a critique of Gilberto Freyre's extensive work regarding the formation of the Brazilian society and its culture, Jessé Souza, professor at the Department of Sociology of the University of Brasília, explains the main factors to consider regarding this complex issue. As the Portuguese started colonizing Brazil, they decided to innovate and try a new structure of colonization: the agriculture of monoculture, the use of slave labour, and the patriarchal family, constituted by the union of the colonizer and Indigenous women. ${ }^{6}$ Freyre argues:

The head of the family and the landlord, owner of the lands and slaves, was the absolute authority in his domains, which forced even El Rei to negotiate. The patriarch had his altar in the house and a private army on his territories. ${ }^{7}$

Regarding the family structure and the relationship between the colonizer and women, Souza refers to Freyre and argues that the patriarchal model represented the whole social pyramid, from the dominant male at the top, with intermediary elements such as bastards, dependents, and domestic slaves, to the bottom of the pyramid where we find the plantation slaves. ${ }^{8}$ Freyre mentions how such structure encouraged the development of a sadistic relationship between the

5 Darcy Ribeiro, O Povo Brasileiro: a Formação e o Sentido do Brasil, (São Paulo: Companhia das Letras, 1995), 108.

${ }^{6}$ Jessé Souza, "Gilberto Freyre e a Singularidade Cultural Brasileira," in Tempo Social, (Vol. 12, n.1, São Paulo: SciELO, May 2000).

${ }^{7}$ Gilberto Freyre, Casa-Grande e Senzala, (Lisboa: Livros do Brasil, 1957), 17-18.

${ }^{8}$ Jessé Souza, “Gilberto Freyre e a Singularidade Cultural Brasileira," in Tempo Social, (Vol. 12, n.1, São Paulo: SciELO, May 2000). 
patriarch and his "subjects": Indigenous and Black women, the White women who were used for reproduction and unilateral sex, and the children, who suffered almost as much physical abuse as the slaves. ${ }^{9}$

${ }^{9}$ Gilberto Freyre, Sobrados e Mucambos, (Rio de Janeiro: Editora Record, 1990), 68 and 71. 


\section{CONTEXT}

\section{Family History in the Context of National History}

My family comes from Northeastern Brazil, a more conservative, patriarchal part of the country if compared to Southern Brazil, where I grew up, close to São Paulo. In my immediate family I always witnessed a faithful submission to the patriarch figure. Men hold a lot of power within the family and dictate what life is like within and beyond it. Women usually serve the patriarch and follow his instructions, mimicking the previous description of the women's behaviour vis-à-vis their "master". ${ }^{10}$

The family's history is obviously "written" by the patriarch: the officially accepted version is to be approved by him. This attitude mirrors the way in which the history of the country has been written since the early days of colonization in the sixteenth century. In the case of my immediate family -- my biological mother, Maria Gecília, and Biatriz, whom I also consider as a mother and who helped raising myself and my siblings - we all lived with a patriarch who reproduced in the twentieth century the typical behaviour of the dominating male from sixteenth century colonial Brazil. This popular saying from Northeastern Brazil seems appropriate and revealing in such context:

O homem decide e quem tiver juízo, que obedeça. ${ }^{11}$

${ }^{10}$ Carole A. Mycofski, "Bounded Identities: Women and Religion in Colonial Brazil, 1550-1750," in Religion (Vol. 28, 4, 1998): http://dx.doi.org/10.1006/reli.1998.0142, 330.

${ }^{11}$ Men decide and whomever is smart enough, obeys. (English translation by Eduardo Nunes Jansen) This popular saying is a variation on the Portuguese saying: Manda quem pode, obedece quem tem juizo (Whomever can command, does it; whomever has good judgment, obeys.) See https://quemdisse.com.br/ frase/manda-quem-pode-obedece-quem-tem-juizo/78782/. 


\section{Memory and Silence}

In his book Os Excluídos do Reino, the Brazilian historian Geraldo Pieroni highlights the way the Portuguese set the example when the secrecy demanded by the Inquisition would be broken in the sixteenth and seventeenth centuries. Whomever dared reveal any secret from the Holy Office would face harsh physical punishment and exile to the colony (Brazil). Sharing information, breaking the heavy law of silence had very serious consequences then. ${ }^{12}$ This very philosophy seems to have been applied in Brazil at different times of the country's history. It seems this mentality is engraved in the country's collective unconscious.

Since colonial times in Brazil, private and public history have often been manipulated in order to suit the needs of whomever held power. In order to erase atrocities or to hide inconvenient truths, history has been "asepticized" and any "true" family history or stories have not been freely carried forward through oral tradition. There was too much to hide regarding the formation of the Brazilian people: the massacre of the native Indigenous population; ${ }^{13}$ the forced migration of four million Africans to work in Brazil as slaves; ${ }^{14}$ the white Europeans, such as the "marranos", who were either exiled in the colony or who chose to escape the Holy Office by pretending to abandon their original faith and convert to Christianity. ${ }^{15}$ Families were then trained to choose carefully between the stories to be told and the ones to hide.

\footnotetext{
12 Geraldo Pieroni, Os Excluídos do Reino - a Inquisição Portuguesa e o Degredo para o Brasil Colônia, (Brasília: Editora Universidade de Brasília, 2000), 239.

${ }^{13}$ Darcy Ribeiro, O Povo Brasileiro: a Formação e o Sentido do Brasil, (São Paulo: Companhia das Letras, 1995), 108.

14 Ibid., 118.

${ }^{15}$ Louis Sala-Molins (Org.), Le Dictionnaire des Inquisiteurs (Valence, 1494), (Paris: Galilée, 1981), 379.
} 
As a teenager, as I started to become more interested in alternative history books, my questioning regarding the history of my own family and my ancestors grew in significant ways. It was then impossible for me to obtain any clear, satisfying answers, and that remained the case until now.

\section{Military Dictatorship and the Erasure of Memory}

I had to do a lot of research to discover some details about my own ancestors. Both my parents were never able to tell me anything substantial about their parents or grandparents' lineage. I always suspected that this ignorance about the past or lack of memory had clear purposes: to hide atrocities committed by ancestors a long time ago; to suppress the fact that some of our ancestors were Jewish people running away from the merciless Inquisition; to protect the family from the dangers of the dictatorial regime in Brazil between1964 and 1985. While this dark law of silence had to be respected for obvious reasons, it also most certainly affected the ability of our family to pass on its story and history by oral tradition or other means, contributing to the annihilation of familial and national memory. ${ }^{16}$

The contemporary history of Brazil suggests that some oppressive patterns from the colonial times have survived when it comes to the ways in which society and culture have evolved since the sixteenth century. ${ }^{17}$ In additon, the 21 years or military dictatorship in the country also contributed to the erasure of memory. During that period, not having an opinion, not knowing or not remembering could make all the difference between life and death. This seems to be a

\footnotetext{
${ }^{16}$ Maurício Lissovsky and Ana Lígia Leite e Aguiar, "The Brazilian Dictatorship and the Battle of Images," in Sage Journals, (Vol. 8, Issue 1, October 8, 2014), http://journals.sagepub.com/doi/abs/ $10.1177 / 1750698014552404$.

${ }^{17}$ Mary Del Priore, “As Mutações da Família Brasileira,” in Aventuras na História, August 2014, http:// www.historia.abril.com.br, 64.
} 
characteristic shared by most countries in Latin America. Brazil is definitely not an isolated case. After World War II and during the Cold War between the United States and the Soviet Union, in many Latin American countries, the civil governments were overthrown and replaced by military dictatorships: Brazil (1964), Argentina (1966), Chile and Uruguay (1973), to name but the most obvious examples, all countries that have been through the same upheaval, be it under different circumstances. ${ }^{18}$ Most of the intellectuals, artists, and students in these countries were brutalized, incarcerated, tortured or murdered. Some "lucky" ones were saved by exile and allowed to return to their homelands after getting political amnesty. ${ }^{19}$ Some survived with life-long scars. Some vanished and were never seen again. When extreme-right forces took over, they "purged" these countries of their vitality, creativity, joie de vivre, constitutional guarantees and democracy.

In Brazil, the military coup happened in 1964, during the same period in which the Bossa Nova flourished. ${ }^{20}$ The socio-political oppositional movements were well organized at that time: student movements (UNE, União Nacional dos Estudantes); unions (such as CGT, Comando Geral dos Trabalhadores, PUA, Pacto da Unidade e Ação); there was even a left wing military movement. ${ }^{21}$ Despite this, it took the country fully twenty-one years to regain the right to vote for a president after the coup. In 1985, a civil president was elected and history again shifted

${ }^{18}$ Adélia Miglievich Ribeiro, "Darcy Ribeiro e o Enigma Brasil: um Exercício de Descolonização Epistemológica," in Sociedade e Estado, (Vol. 26, n.2, Brasília: May/Aug. 2011), http://dx.doi.org/ 10.1590/S0102-69922011000200003.

${ }^{19}$ Ibid.

20 "Blame it on the Bossa Nova" was the title of a song written by Cynthia Weil and Barry Mann, which was a 1963 hit single for Eydie Gormé in the United States of America that same year. The United States have allegedly financed the military dictatorship in Brazil and also provided training in torture techniques to Brazilian military officials.

${ }^{21}$ D. Paulo Evaristo Arns (Org.), Brasil: Nunca Mais - Um Relato para a História, (Petrópolis: Editora Vozes, 1990), 89-116, 117-154. 
radically in Brazil: the dictatorship was finished and thus a completely new country had to be created.

During the darkest and most dangerous first decade of the dictatorship, there were no more laws ensuring the citizens' safety. There was no more concept of citizenship itself. At any time of the day or night, the police could knock at your door and arrest anyone under the suspicion of 'subversive activities'. All these arrests were done illegally, usually with the individual ending up in a special kind of prison where she/he would be tortured and, most probably, murdered. ${ }^{22}$ Many people simply "disappeared" -- never to be seen or heard from again.

\section{Hierarchy and Social Structure in Brazil}

When I started working on my film A Magic Thread, I was forced to investigate my own identity as an individual, considered in Brazil a White male, part of a Brazilian family whose history was both complex and mysterious to me.

Antônio Sérgio Guimarães' thoughts about the formation of the Brazilian people inspired me to think of my own 'race' and what that means within the family structure. Guimarães argues that the White people in Brazil were not formed by a simple ethnic mix of European peoples. In Brazil, mestizos and pale mulattoes are considered White if they are Christian and literate (the colonial European dominant elements). ${ }^{23}$

As I thought about my family structure and analyzed the role played by each of its members, it was clear to me that I was looking at an institution based on a very old colonial patriarchal organization imposed by the Portuguese colonizers as they settled in Brazil from the sixteenth

22 Ibid., 77-80.

${ }^{23}$ Antônio Sérgio Alfredo Guimarães, Racismo e Anti-Racismo no Brasil, (São Paulo: Editora 34, 1999), 47. English translation by Eduardo Nunes Jansen. 
century on. For example, my father always acted in a way that would allow him, by 'nature' or by force, to be the head of the family and its (supposedly) most powerful member. The Brazilian historian Mary Del Priore points out how patriarchy was shaped in a very particular way in Brazilian society:

... the particularity of the patriarchal family is that it was not restricted to the trio: father, mother and child. The family was constituted by relatives, illegitimate or adopted children, godchildren, employees, friends, slaves and aggregates. Ties of dependency and solidarity united the family members. ${ }^{24}$

My father's behaviour and attitudes in the household and towards the other members of the family, especially the women, never really made any sense to me, even when I was a child. $\mathrm{He}$ always expected the females to be subservient, available, obedient models of 'good women' according to his patriarchal standards and visions.

We migrated from Northeastern Brazil to the south part of the country, to the state of São Paulo, between 1969 and 1970. My mother needed medical attention in a more prosperous environment because she had developed breast cancer. My mother's diagnosis was delivered by a male doctor to my father while the woman herself, the patient, sat in the waiting room outside of the doctor's office. The men decided that it would be better for my mother not to know her own diagnosis. So they decided, using their power as men, as a doctor and as a husband, to keep my mother in ignorance. Like most of the girls from her generation, my mother was taught that a respectable woman had to listen to her father (or her oldest brother, in the absence of the father) and later to her husband. She would never dare questioning the male authority or contradict it. The role of the good woman, daughter, wife, was to be completely submissive to the authority of

\footnotetext{
${ }^{24}$ Mary Del Priore, Histórias e Conversas de Mulher, (São Paulo: Planeta do Brasil, 2013), 13. English translation by Eduardo Nunes Jansen.
} 
the main male in her life. This way of raising and educating girls (and boys) was reinforced in the family, in society and also by religion, as Mary Del Priore argues in her analysis of the subject. $^{25}$

The dominant religion in Brazil has always been the Catholic Apostolic Roman religion, although Brazil has been invaded by different evangelical churches (imported from the United States) in the past 30 years. ${ }^{26}$

My biological mother was born and raised in a household that had been structured following the colonial parameters. Although my maternal grandparents were not considered to be part of the elite, they were landowners. This fact alone placed them on the top of the social pyramid in the heart of the Brazilian sertão (the Northeastern arid countryside), where owning land represents power vis-à-vis other less fortunate families who depended on the landowners for work. ${ }^{27}$ My grandparents were not wealthy, but owning land gave them an elitorian status. In this context, as Carole Myscofski explains, mimicking the ideal of the colonial elite, women were expected to remain virgins until marriage, to be "virtuous", "invisible" to society, and respectful of the Catholic doctrines. ${ }^{28}$

Biatriz, the woman I consider to be my second mother, and who helped my biological mother raising my siblings and I, came from a family that was at the bottom of the social pyramid in

\footnotetext{
${ }^{25}$ Mary Del Priore, “As Mutações da Família Brasileira,” in Aventuras na História, August 2014, http:// www.historia.abril.com.br, 64.

${ }^{26}$ J.B.B. Pereira, Religiosidade no Brasil, (São Paulo: Edusp, 2013). http://dx.doi.org/10.1590/S0103-40142013000300022

${ }^{27}$ Fabiana Vezzali, "Especial Latifúndio - Concentração de Terra na Mão de Poucos Custa Caro ao Brasil," http://reporterbrasil.org.br/2006/07/especial-latifundio-concentracao-de-terra-na-mao-de-poucoscusta-caro-ao-brasil/, 11/07/2006.

${ }^{28}$ Carole A. Mycofski, "Bounded Identities: Women and Religion in Colonial Brazil, 1550-1750," in Religion Vol. 28, 4, 1998, http://dx.doi.org/10.1006/reli.1998.0142 : 329-337.
} 
Northeastern Brazil. Her family did not own land and depended on the landowners to work. She was sent to my grandparents' farm at age 13 in order to help my grandmother around the house and at the same time, to be trained in the kitchen and to do household work in exchange of a place to live, food and clothing. Nowadays, this arrangement could be qualified as being exploitation of a minor and slavery. ${ }^{29}$ Back then, in 1956, only a decade after the end of World War II, when Biatriz started working at my grandparents' farmhouse, this was a way for her family to make sure she was being trained to do domestic work, while being fed and dressed. There was no "other" financial compensation in this arrangement. This way, Biatriz grew up with my biological mother and her many siblings as a kind of 'family member'. Although I heard in the past a mention to Biatriz growing up in that environment as a 'sister' to my grandparent's children, the hierarchy and the differences in treatment between the family's own siblings and Biatriz were always obvious. There has always been some camaraderie and emotional attachment between the family and Biatriz, but she was constantly directly or indirectly reminded of her duties as a domestic help. Biatriz' story is not an isolated case in the history of Brazil: it represents the very oppressive nature of Brazilian society as it was formed since its initial colonial times. ${ }^{30}$

The role Biatriz played in my maternal grandparents' farm mimics, in my opinion, in the twentieth century, a 'slavery' model brought to Brazil by the Portuguese during colonial times. Gilberto Freyre raised this issue during a conference at the University of Stanford, in California,

\footnotetext{
${ }^{29}$ Eduardo Paulo Girardi, Neli Aparecida de Mello-Théry, Hervé Théry, and Julio Hato, "Mapeamento do Trabalho Escravo Contemporâneo no Brasil: Dinâmicas Recentes," in Espaço e Economia - Revista Brasileira de Geografia Econômica, Ano II, Número 4, 2014, https://espacoeconomia.revues.org/804.

${ }^{30}$ Darcy Ribeiro, O Povo Brasileiro: a Formação e o Sentido do Brasil, (São Paulo: Companhia das Letras, 1995), 446.
} 
in 1931, as he compared the slavery system in Brazil and the rest of the Americas: according to him, the Brazilian slavery system followed the Arabic model, in which the slave is practically a family member, not a "working machine." 31

Carole Myscofski highlights some of the social and religious aspects of oppression, discrimination and exclusion against women belonging to the lower classes, Brazilian Indigenous women or women of an African descent during colonial times: slave women were considered to be untrustworthy and inclined to prostitution; a poor girl's education represented training in domestic service; the Catholic Church itself would make marriage impossible for slave women by "requiring the publication of banns in the couple's home towns"; these vulnerable groups of women were sexually exploited in the colonial system by the political and religious authorities, being forced to live in "concubinage" or "cohabitation" with single men ("including priests"). ${ }^{32}$

The impact of these historical facts can still be seen in the realities of Brazilian contemporary society. ${ }^{33}$ I see clear parallels between the past and the present within my own immediate family. These themes are taboo, if not in Brazil at large, at least in my family. Religion still occupies a very important place within the family and it holds its power to control behaviour, manipulate people and censor life. My two mothers are still immersed in this religious domination process. They are both catholic. Their faith, devotion and loyalty to the Church, the same powerful institution that has been oppressing them and other women for centuries, is an important part of their everyday life.

\footnotetext{
${ }^{31}$ Veja Revista, (São Paulo: 15/09/1999), 71. English translation by Eduardo Nunes Jansen.

32 Carole A. Mycofski, "Bounded Identities: Women and Religion in Colonial Brazil, 1550-1750," in Religion Vol. 28, 4, 1998, http://dx.doi.org/10.1006/reli.1998.0142, 329-337.

${ }^{33}$ Mary Del Priore, “As Mutações da Família Brasileira,” in Aventuras na História, August 2014, http:// www.historia.abril.com.br, 64.
} 
Brazil is a land of enormous contradictions. The way its society was structured following a strict hierarchy is a good example of the previous statements. ${ }^{34}$ In the case of my biological mother's family, these contradictions are very apparent to me. Though poor, they were landowners and this placed them on the top of the social pyramid in the rural environment of Northeastern Brazil. The family was an ardent Catholic one, honoring the religion that was brought to the country by the Portuguese colonizers in the sixteenth century. However, there are tales, clues and facts that strongly suggest there were Brazilian Native and Sephardic Jewish ancestors in the family. These aspects of the family history are never discussed openly. One needs to do intensive research and look for the subtle signs that prove the mixed and culturally diverse background of the family. Throughout Brazilian history, the Indigenous peoples were always treated as being inferior to the Whites, while Jewish people were sent to Brazil as outcasts as a punishment under the Inquisition, with the imposed condition that they converted to the Catholic religion.

A few centuries after the colonization of Brazil by Portugal, a dark veil seems to cover this 'forbidden history'. Most families preferred to have a strong identity as "Brazilian people," making all kinds of efforts to look and act as "White people" and to be as wealthy as possible..$^{35}$

Biatriz, my second mom, has very little knowledge and information about her own family's background. She seems to come from a very mixed family as well: there's probably some European, African and especially Brazilian Indigenous blood in her lineage. I do not yet have

\footnotetext{
${ }^{34}$ Ribeiro, O Povo Brasileiro, 120.

${ }^{35}$ Ibid., 453.
} 
concrete proof for this supposition, but I believe Biatriz is in part a descendent of the extinct Brazilian Indigenous people, the Cariris, exterminated as a tribe by the Portuguese colonizer. ${ }^{36}$

The attitude of the European colonizers towards the native population of the Americas is a shameful, dark chapter in the History of the world. The narrative regarding the fate of the Indigenous population is unfortunately not different in Brazil. Contemporary historians agree to call it a genocide when they refer to the History of Indigenous peoples in Brazil. The historian Maria Idalina Pires describes this terrible episode of Brazilian colonial history in a way that helps us to draw a parallel between the situation then and what is still happening to Indigenous peoples today: the Portuguese violent style of colonization of the countryside in Northeastern Brazil included wars against the Indigenous tribes. These armed conflicts "had a genocide characteristic" and targeted the most combatant tribes such as the Açu and the Cariri nations. ${ }^{37}$

On a recent visit to Ryerson University, Flávio de Leão Bastos Pereira, a professor of Human Rights and Constitutional Law at Mackenzie Presbyterian University in São Paulo, lectured about the genocidal processes that have victimized the Indigenous nations of Brazil from the beginning of colonial times and throughout Brazilian history, but especially during the military dictatorship period (1964-1985). ${ }^{38}$ The social and economic models planted by the Portuguese

\footnotetext{
${ }^{36}$ Gustavo Barroso, À Margem da História do Ceará, (Fortaleza: Imprensa Universitária do Ceará, 1962).

${ }^{37}$ Maria Idalina Pires, "Guerra dos Bárbaros - O Terrível Genocídio que a História não Conseguiu Esconder”, in Dicionário de Datas da História do Brasil, (São Paulo: Editora Contexto, 2016), https:// www.editoracontexto.com.br/blog/guerra-dos-barbaros-o-terrivel-genocidio-que-a-historia-oficial-naoconseguiu-esconder/. English translation by Eduardo Nunes Jansen.

${ }^{38}$ https://www.ryerson.ca/news-events/events/2017/01/iid-series-brazilian-indigenous-nations/.Flávio de Leão Bastos Pereira was part of the Brazilian National Truth and Reconciliation Commission and serves both the International Network of Genocide Scholars as well as the Roster of Experts of the International Nuremberg Principles Academy.
} 
colonizers have such deep roots in Brazilian society, that it continues to bloom as a shameful, horrendous weed.

Last but not least, the peoples of African descent brought forcefully to Brazil by the Portuguese colonizers as slaves, combined their genes, culture and suffering with the other peoples in the country to form what we know today as Brazilians. Darcy Ribeiro draws attention to this particular history: from 1538, Africans were brought in great numbers to Brazil as slaves in order to support the sugar cane culture, a European business "in which were invested immense amounts of money." 39

This gigantic colonial enterprise was made possible thanks to the violent, incessantly coercive and dehumanizing appropriation of human beings, who were reduced to objects whose only reasons of existence were securing the functionality of the system and protecting the White man's interests. ${ }^{40}$

According to Gilberto Freyre, a sadistic attitude towards Black peoples and people who are in a position of inferiority was engraved onto every Brazilian individual of a certain higher social class through the subtle mechanisms of education throughout the generations, even if that individual was born and raised after slavery was finally abolished in Brazil on May 13, 1888. ${ }^{41}$

Only 129 years separate us from the time when slavery was still a legal reality in Brazil. As we look at the situation of Black peoples and their descendants in Brazil today, we realize that the slavery and inferiority stigmas attached to skin colour and the ethnic background of an

\footnotetext{
${ }^{39}$ Darcy Ribeiro, "O Povo Brasileiro: Crítica ou Reforço à Noção de Caráter Nacional Brasileiro?” in Alice Anabuki Plancherel (Org.), Memória e Ciências Sociais, (Maceió: Edufal, 2005), 161. English translation by Eduardo Nunes Jansen.

${ }^{40}$ Ribeiro, O Povo Brasileiro, (São Paulo: Companhia das Letras, 1995), 118.

${ }^{41}$ Gilberto Freyre, Casa-Grande e Senzala, (Lisboa: Livros do Brasil, 1957), 354.
} 
individual are still part of reality: prejudice, discrimination and exclusion make that segment of the Brazilian society a very vulnerable one. ${ }^{42}$

There is a movement now that promotes the need for a Black conscience, but being poor and a Black individual or, worse still, a poor Black woman in Brazil, is still a harsh reality to face. ${ }^{43}$

\section{Being Queer in Brazil}

In order to understand the historical order of things, it's important to remember that there was a queer presence in Brazil already in the early years of the colonizing process. The Portuguese Inquisition would initially sentence "sodomites" to exile in the colony. White Portuguese settlers, members of the clergy, African slaves, and Indigenous people were already persecuted then for being queer. ${ }^{44}$

Following the old colonial, patriarchal traditions of intolerance, prejudice, oppression, exclusion, discrimination, violence and murder against minority groups, contemporary Brazil still seems to be very traditional and loyal to its roots. The list of phobias against people under the LGBTQ2 umbrella is endless and historical. This is certainly not a new issue.

\footnotetext{
${ }^{42}$ Ires Aparecida Falcade, "Capitalismo, Direitos Humanos e Encarceramento no Brasil," in II Congresso Internacional de Direitos Humanos e Políticas Públicas - Desigualdades e Intolerâncias em Tempos de Crise, Pontifícia Universidade Católica do Paraná, 2016, 70.

43 Janaína Macagnan de Souza, Mário Estevam dos Santos Souza, and Willian Alves dos Santos, "Direitos Humanos e Consciência Negra: Identificação da Cultura Afro-Brasileira na Sala de Aula," in II Congresso Internacional de Direitos Humanos e Políticas Públicas - Desigualdades e Intolerâncias em Tempos de Crise, (Pontifícia Universidade Católica do Paraná, 2016), 371.

${ }^{44}$ Several examples of this phenomenon are: Estevão Redondo, the first homosexual sent for exile in Pernambuco, northeastern Brazil, in 1547. See: Arquivo Nacional da Torre do Tombo, Inquisição de Lisboa, Processo 352. Priest Frutuoso Álvares, the first homosexual victim of the Inquisition in Bahia, northeastern Brazil, in 1591. See Arquivo Nacional da Torre do Tombo, Inquisição de Lisboa, Processo 5866. Francisco Manicongo, African slave, first transvestite in Salvador, Bahia, northeastern Brazil, in 1591. Primeira Visitação do Santo Ofício à Bahia, Denunciações, 406-407. Jerônimo Parada, student, first male prostitute in Bahia, northeastern Brazil, 1591. Arquivo Nacional da Torre do Tombo, Inquisição de Lisboa, Processo 5866. Diogo Botelho, $5^{\text {th }}$ Governor of Brazil, in 1605. Segunda Visitação do Santo Ofício à Bahia, Denunciações, 380-384. Luiz da Câmara Coutinho, General Governor of Brazil, end of seventeenth century. Gregório de Matos, Obra Completa, (Salvador: Editora Janaína, 1969), 150-217.
} 
Different Queer voices from Latin American countries that went through similar violent colonization processes and where minorities are still oppressed in the present, are inspiring a discussion about the Brazilian situation today. For example, Rafael de la Dehesa analyzes the political, social and economical challenges in Brazil from a queer perspective. ${ }^{45}$

One of the oldest gay groups in Brazil, Grupo Gay da Bahia, releases annual reports regarding crimes committed against people who belong to the LGBTQ2 group. The statistics are terrifying. Brazil is definitely a world leader when it comes to crimes against sexual minorities. In 2016 alone, the most violent year since 1970 regarding crimes against LGBTQ2 people, 343 queer people were murdered in Brazil. In 2017, there were 23 documented murders from the beginning of the year until January $22^{\text {nd }}$ only. A hate crime/murder happens every 25 hours in Brazil. ${ }^{46}$

In A Magic Thread, I mention a childhood memory: I remember my father saying at the table, as the family had a meal, that he'd rather have a criminal or a dead son than a faggot one. I had no idea what that word meant, but I felt the comment was aimed at me personally, like a sharp arrow.

\footnotetext{
${ }^{45}$ Rafael de la Dehesa, Queering the Public Sphere in Mexico and Brazil-Sexual Rights Movements in Emerging Democracies, (Durham and London: Duke University Press, 2010), 141. Testimonial by Jorge Luiz de Souza, Workers' Party LGBT sectorial of Rio de Janeiro, in discussion with author Rafael de la Dehesa, Rio de Janeiro, 4 July 2001: "In that respect, I knew I was different than other people. My sexual relations were no longer with women but with men. Then something happened and I started becoming conscious of class. I began to see that we were being massacred in the favela because we were black, because we were favelados, because we didn't have money, because we were excluded from society. And that is the discussion that we took to the community. That's where I became aware of what it means to be homosexual in a favela, what it means to be a black homosexual, a homosexual with no money, a homosexual who is not in the organized groups."
}

${ }^{46}$ Grupo Gay da Bahia, Relatório 2016 - Assassinatos de LGBT no Brasil, https:// homofobiamata.files.wordpress.com/2017/01/relatc3b3rio-2016-ps.pdf. 
As I experienced personally in my family as a direct result of my father's patriarchal mentality inherited from sixteenth century colonial times in Brazil, violence, prejudice, discrimination against LGBTQ2 people often starts at home. An environment that should be the safest place for any individual, often becomes the first threat that LGBTQ2 people have to face, and this from a very early age. Personally, I was lucky to have experienced nothing but psychological violence from my father at home. I was also surrounded by two strong women who played their roles as mothers and protectors in a wonderful way. I guess I am that much luckier than a lot of individuals for never having been exposed to physical violence against myself or against my mothers. I am fully aware that this is not the same for everyone.

In December 2016, the teenager Itaberli Lozano was murdered at home because he was gay. His own mother stabbed him to death with the help of her husband. Then, mimicking the ancient Inquisition tradition, Itaberli's body was burned. His carbonized remains were then buried in a sugar-cane plantation field by his murderers. ${ }^{47}$

Geraldo Pieroni explains this ritual performed by the Inquisition as a form of punishment for "sodomites:" 48

The Afonsinas, Manuelinas and Filipinas Ordinances establish the death penalty for sodomites: “...he shall be burnt and turned into dust by fire, so that no memory may be kept of his body and sepulture." 49

Amongst the many contradictions in Brazil, there is the following one: every year the world's most impressive Gay Pride celebration is held in São Paulo. The event was included in the

\footnotetext{
${ }^{47}$ Ibid.

${ }^{48}$ Pieroni, 136.

49 Ordenações afonsinas, Livro V, Título XVII: "Dos que cometem pecado de sodomia". According to A. H. Oliveira Marques, until the present day no document was found regarding the condemnation to death of a sodomite directly by civil justice, apud Luis Mott, 705. English translation by Eduardo Nunes Jansen.
} 
Guiness Book of Records as the biggest LGBTQ2 celebration in the world, including 2,5 million people in 2006 and 3 million individuals in $2017 .{ }^{50}$ This while, Brazil is the number one country in the world in terms of LGBTQ2 people being murdered. ${ }^{51}$

\section{A Personal Search for Identity}

My sexual orientation has never been discussed openly within my family. I left Brazil when I was 19 years old to come to Canada and up until that moment, my family still chose to believe I was heterosexual.

As a very young child, I remember already having an intuitive notion of my own nature. I knew I was different, I just didn't know how and what exactly that meant. I had no words to talk about it. Nobody talked about it. There were simply no positive queer models to follow.

In my family, I would see my two mothers working very hard. The two women have always been a great duo. I don't remember them talking, making plans or discussing strategies, but they were always on the frontline, dealing with the many challenges life threw at us every single day: economic difficulties, adaptation issues (we were poor migrants from Northeastern Brazil, with habits and accents that were often not understood and/or mocked in the South), the lack of family/friends support, to name but a few. These strong, determined, wise women (despite the fact they were both officially uneducated) showed us the way. My father always played the role of the man he was taught to be: he expected to be heard, obeyed and served. As a child and a

${ }^{50} \mathrm{https://viagenscinematograficas.com.br/2017/05/parada-do-orgulho-lgbt-sao-paulo.html.}$

${ }^{51}$ Grupo Gay da Bahia, Relatório 2016 - Assassinatos de LGBT no Brasil, https:// homofobiamata.files.wordpress.com/2017/01/relatc3b3rio-2016-ps.pdf. 
teenager, I often asked myself why we needed him at all. As an adult, I am now able to understand his behaviour, but not then.

For a boy like me, growing up gay in the 1970's in Brazil, in a typical conservative lower middle class family from one of the most macho-dominated parts of the country, women have always been a source of joy. Women were models of ability, strength, a great deal of beauty and nobility. This created a great conflict for me as a queer man. I craved for a male role model to follow, but only admired and respected everything my two mothers were doing in my family for all its members. I wanted to be a different, good kind of man who supported and celebrated women's qualities without oppressing them or placing obstacles on their path of development and growth as human beings, like my father did. My quest for the finest example of the man to be and the ideal identity to adopt, started very early in my life, inspired by the two wonderful female models I had at home. 


\section{DOCUMENTARY RELEVANCE}

\section{The Challenges of Telling my Own Story}

I initially thought that A Magic Thread could be heavily criticized and labeled as a selfcentered/navel-gazing kind of film. Yet I stayed true to my initial idea. I hope that my film is an "honest autobiographical film", as described by Michelle Citron:

This is the implicit threat that autobiography poses to the status quo. As a culture, we have been little able to tolerate the truth of the variety of lived experience: that truth threatens the social order. The autobiographical act is historically significant for women, and all others, who have traditionally lacked either a voice or a public forum for their speaking. ${ }^{52}$

My narrative includes talking about problematic themes, uncomfortable political and social realities. It exposes aspects of my subjects' complex lives: people who are family or whom I consider like family.

In my search for inspiration and models from other artists whose work involves selfreflection, I found this in Catherine Russell's description of how, in A Berlin Chronicle, Walter Benjamin offers fragmentary recollections that:

... situate him as a child within a complex network of social relations. A class analysis is projected onto fleeting memories, along with a recognition of gender roles, and even an analysis of the gaze. ... Throughout his various autobiographical writings, a sense of the self emerges that is thoroughly grounded in experience and observation. ${ }^{53}$

In a similar way, through the lens of my own childhood, my memories, and the strong feminine role models I had around me, I built my personal narrative for A Magic Thread.

\footnotetext{
52 Michelle Citron, "Fleeing from Documentary: Autobiographical Film/Video and the 'Ethics of Responsibility"' in Diane Waldman and Janet Walker (eds.), Feminism and Documentary, (Minneapolis, London: University of Minnesota Press, 1999), 272.

${ }^{53}$ Catherine Russell, Experimental Ethnography - The Work of Film in the Age of Video, (Durham and London: Duke University Press, 1999).
} 
I see my work as autobiographical and auto-ethnographical in the same sense that it is constructed around essential questions regarding self-identity, family and the history of the country where I was born, class identity and recognition, memories, family/historical memory and the lack thereof. Russell draws links between autobiography and ethnography in a way that echoes my decisions as a filmmaker and my own analysis of the film:

Autobiography becomes ethnographic at the point where the film or videomaker understands his or her personal history to be implicated in larger social formation and historical processes. Identity is no longer a transcendental or essential self that is revealed, but a "staging of subjectivity" - a representation of the self as a performance. ${ }^{54}$

The understanding of my identity, for myself and for others, is necessarily linked to the political, social and historical facts that I inherited from family, "adopted family" and ancestors. It is deeply rooted in the social environment and the country where I was born and where I grew up. This complex web that shaped my identity is the consequence of migratory movements and displacement, sexual orientation, self-identification with minority groups etc.

A Magic Thread was conceived with all these factors in mind. Although the film is a first person narrative, other subjects still deliver key elements of the story through interviews. The "narrator" (myself) adopts a role of adding essential information, contextualizing the images and building bridges between subjects whose connection with each other might not seem clear initially.

\section{Creating Spaces Through Documentary Practice}

When I decided to talk about my personal life and expose my family's intimate personal stories, my main motivation was to create a positive space where my subjects and myself would

${ }^{54}$ Ibid. 
not be silenced, censored or pushed into closets. I therefore define this work as a queer film because I expose in it the realities of a gay man, of women oppressed by a patriarchal society as well as of a trans-woman facing many challenges on her personal quest for happiness in a country like Brazil.

Different artists and documentarians inspired me on my journey. Agnès Varda's strong, melodious, poetic voice has always been a magnificent inspiration, especially her films Les Plages d'Agnès ${ }^{55}$ and Les Glaneurs et la Glaneuse. ${ }^{56}$ AgnèsVarda shows in these films her moving ability to share personal, intimate stories with dignity and beauty. I thought a lot about her story telling style in order to find the right tone for my own personal narrative. In Les Glaneurs et la Glaneuse, Varda draws parallels between aspects of her own life as a glaneuse and her subjects' lives, the same way I connected my own struggles and memories to the elements presented by my subjects in the film. In an attempt to capture my images in the most personal and artisanal way possible, I often used a camcorder I own to minimize the physical and psychological technological obstacle between my subjects and myself. Varda uses the same camera in her images shot from the car on the road, as she performs a child-like ritual of stretching her hand and pretending she is holding the trucks that she passes by on the highway. In Les Plages d'Agnès, her playful approach to present her memories as a series of family photographs displayed like frames on the sand of the beach where she used to spend time as a child with her family, inspired me to use my own family's photographic archive as a way to recapture a lost, mysterious past and present it as an intimate, poetic way of telling my story.

\footnotetext{
55 Agnès Varda, Les Plages d'Agnès, (Paris: Ciné-Tamaris and Arte France Cinéma, 2008).

${ }^{56}$ Varda, Les Glaneurs et la Glaneuse, (Paris: Ciné-Tamaris, 2000).
} 
Varda's narration in these two films helped me getting over my initial fears of using my own voice-over throughout my whole film, thus finding and claiming my own voice in a literal and metaphorical sense.

Regarding the creation of and the constant struggle for a queer space where I would be free to do my work and pose the questions my film raised, other artists and films also inspired me.

The notions of existence and space seem essential as we discuss the importance of locale/ place/space in queer documentary. As I analyze Weissman and Fernie's 1992 documentary Forbidden Love: The Unashamed Stories of Lesbian Lives, the importance of space is obvious from the moment the film was being produced. As Jean Bruce points out, The National Film Board of Canada had a particular space at that very moment, the women's unit, Studio D, “an overtly feminist space within the NFB with its visionary leader, Rina Fraticelli." ${ }^{57}$

Creation and appropriation of public space allowing women to establish private spaces and live lesbian identities in a free, positive way also seems essential for the analysis of this film and its social/historical/political context. These aspects mirror some of the realities I wished to expose in A Magic Thread. In Canada, as Bruce and Gerda Cammaer remind us, ... it was not until 1985 that prohibitions against discrimination were officially mandated by Section 15 of the national Charter, and only in 1996 that sexual orientation became protected under the Human Rights Act. 58

In Brazil, the legal protection of individuals based on sexual orientation or gender expression is still not as advanced as in Canada. In the Brazilian context, ultra-conservative and religious

\footnotetext{
57 Jean Bruce, "Queer Cinema at the NFB: the 'Strange Case' of Forbidden Love," in Jim Leach and Jeannette Sloniowski (eds.), Candid Eyes: Essays on Canadian Documentaries, (Toronto: University of Toronto Press, 2003), 164-165.

${ }^{58}$ Jean Bruce and Gerda Cammaer, Forbidden Love: A Queer Film Classic (Vancouver: Arsenal Pulp Press, 2015), 19-20.
} 
forces represent the main obstacles for the advancements in legislation to protect LGBTQ2 people.

Forbidden Love is an example of a hybrid documentary that counts on both non-professional and professional actresses. Nine rebellious and expressive women tell their personal stories. This was a political act, where people fought to connect with each other, to establish positive spaces, as Bruce and Cammaer argue:

Cinematic representation is a vital means by which we can gather together historical and contemporary resources - from archives, interviews, newspaper accounts, and even the world of bars - and by gaining such visibility, become known to each other again. This is itself a political act. ${ }^{59}$

The voice of the film and the voices of the actresses selected to build this documentary are very well aligned. I hope I was able to find a similar fine balance regarding my own voice in $A$ Magic Thread. In every aspect of the production, one can say with confidence that all the participants (in front and behind of the camera) contributed to maintain a nurturing positive space for creativity and freedom of expression. This successful aspect of Forbidden Love solves a problem raised by Waugh and Nichols when considering the nature of hybrid documentaries:

Nichols' criticism is directed at those documentaries in which the authority of the filmmaker is diffused through, or uncritically hidden behind, the voices of the subjects. ...Although "interviews diffuse authority," Nichols argues, a gap remains between the voice of a social actor recruited to the film and the voice of the film... The greatest problem has been to retain that sense of a gap between the voice of the interviewees and the voice of the text as a whole. ${ }^{60}$

In A Magic Thread, similar queer elements of struggle and the subjects are mainly represented by myself as the gay narrator and director as well as by my trans-sister. The realities

\footnotetext{
${ }^{59}$ Ibid., 44.

${ }^{60}$ Thomas Waugh, "The Right to Play Oneself: Looking Back on Documentary Film," Visible Evidence Series, (Vol. 23, Minneapolis: University of Minneapolis Press, 2011), 83.
} 
of the two mothers also mirror the continuous feminist battle for space and equality in a patriarchal society.

In Weissman and Fernie's film, it seems obvious that the questions the documentary raises regarding lesbian identity, private and public spaces, visibility and respect are part of the dialogues and negotiations between LGBTQ2 communities and a hetero-normative society in Canada at that time. The subjects and myself in A Magic Thread face similar challenges under different circumstances. Our voices and narratives politically challenge the oppressive status quo in Brazil.

Tongues Untied, a 1989 documentary by Marlon Riggs, addresses similar questions regarding private and public spaces for members of the Black LGBTQ2 community in the United States. This is a work that could be compared to a photograph within a photograph and so on. Riggs articulates and represents the discourse of the minority within a minority: he is Black and gay. Place of privilege is shown to exist within the LGBTQ2 community because the black gay identity brought forward by Riggs carries a double stigma: racism and homophobia. In A Magic Thread, there is a difficult duality in my own subjects as well: the two mothers face challenges for being women and for not belonging to a privileged social class; while the trans-sister faces challenges for coming from the same social class, for being trans and for fighting to have the right to become a woman, so that her body matches her psychological gender identity.

Another complex layer surfaces in Riggs' film, showing how Afro-American gay men are oppressed by homophobic and racist attitudes of both dominant whites and patriarchal blacks. Both cultures are also hetero-normative. This battle with the impositions and oppression of patriarchy is a common element between Riggs' film and my own. 
When it comes to the notion of spaces, Tongues Untied shows how these oppressive forces usually create negative spaces. Riggs begs to differ and defiantly challenges these impositions, by creating psychological and physical positive aspects and celebrating...

... gay culture in its performative aspects, featuring 'Snap! divas' and vogue dancers along with documentary footage of the civil rights movement.... Riggs provides the reflexive, poetic voiceover, in which he moves from shame and dealing with the death of friends from Aids to acceptance and embrace of his sexuality. ${ }^{61}$

Riggs' documentary also tries to create a positive psychological queer space, which is what I wished to achieve in A Magic Thread.

In Tongues Untied, the intellectual and artistic activity of understanding the past through its historical hurtful details, then analyzing the contemporary position of a double-layered oppression of the African-American queer community and articulating a political claim at the same time is an extraordinary accomplishment. In my film, the historical background is present, though in a more subtle way. The audience needs to have some knowledge of Brazilian history and society to perceive the layer of social questioning raised by the subjects' stories.

These tasks become increasingly more difficult when the oppressed also have to deal with discrimination, loss and trauma. While discussing trauma, Cathy Caruth talks about these challenges and touches on the notion of place, stating that even trauma claims a specific psychological and physical space. Yet, the history that is attached to trauma seems to have no place in the individual's timeline, causing therefore incomprehension, confusion and the impossibility of coming to terms with the traumatic experience.

\footnotetext{
${ }^{61}$ Barry Keith Grant and Jim Hillier, 100 Documentary Films - BFI screen guides (London: Palgrave Macmillan, 2009), 220.
} 
The trauma is the confrontation with an event that, in its unexpectedness or horror, cannot be placed within the schemes of prior knowledge - that cannot, as George Bataille says, become a matter of "intelligence" - and thus continually returns, in its exactness, at a later time.... In its repeated imposition as both image and amnesia, the trauma thus seems to evoke the difficult truth of a history that is constituted by the very incomprehensibility of its occurrence. ${ }^{62}$

Starting from trauma, discrimination and oppression, Tongues Untied serves as a bridge to encourage and facilitate dialogue between and across different communities. Effective communication creates positive spaces. I hope the same is true for A Magic Thread. Like in many wars, this is a question of conquered territories, the ways and means to maintain them and to keep pushing oppressive boundaries, one battle at the time.

${ }^{62}$ Cathy Caruth, "Recapturing the Past: Introduction," in Trauma: Explorations in Memory, (Baltimore and London: The John Hopkins University Press, 1995), 153. 


\section{METHODOLOGY}

\section{How the Film was Born}

I always felt the need to know exactly who I descended from in order to understand myself better and to be able to build a strong identity for myself. This need became more important as I understood, from an early age, that I was a "different" child: my queer identity started taking shape as I was still very young.

I spent my whole childhood and adolescence in Brazil in the 1970s and 1980s, asking my parents in vain about their family's history. The impossibility of getting clear answers made this quest even more challenging and appealing to me. I all but gave up until a few years ago when I found a green tin case buried in my father's closet in his house in Monteiro. It contained some original and historical documents from my family’s "lost” past. My father had no idea whom those documents belonged to and whose names were those on the papers. The documents showed that one of my father's ancestors, Felippe Jansen de Castro e Albuquerque, obtained his bachelor in law at the Université de France à Paris in 1827. It took me a few years to convince my father to let me keep the documents. But even before I was allowed to "inherit" the papers, I felt that a process had been set in motion and that it was, from that moment on, my responsibility to revive that important part of our history. That's the precise moment when my film started.

In early 2016, I went to the Archives Nationales de France in Paris, having nothing but Felippe's name and graduation year in my hands. Hidden in the archive boxes was an entire file on my ancestor Felippe. I discovered it thanks to Felippe's scandalous behaviour for the times: as a young student in Paris, Felippe had a shameless forbidden love affair with a courtisanne, a femme publique, with whom he lived from 1825 until 1827. This liaison dangereuse was 
condemned in writing by different French ministres, such as Messieurs le Comte/le Duc etc.

Felippe faced prejudice, judgement, discrimination because of the individual he loved and the nature of their relationship. I was immediately drawn to his story and I could relate to it as a gay man living in an oppressive society such as $20^{\text {th }}$ century Brazil. This narrative also seemed to be very similar to Alexandre Dumas fils' novel La Dame aux Camélias, turned into a play, and later into an opera by Giuseppe Verdi, La Traviata. These romantic, theatrical and operatic elements opened the door to consider performative elements for my project and choose a more dramatic style to treat its themes and my subjects. I started drawing parallels between Felippe's life and my own: we both left behind an oppressive family structure and society in order to study abroad and experience personal freedom. We both rejected he (post)colonial isolation we experienced in Brazil and moved to more progressive societies hoping to find happiness.

\section{The Feminine Element}

As I studied the letters found in Felippe's file at the French archives, I quickly realized that I could have access to my ancestor thanks to a woman. But she was made invisible by the (male) authorities in France and in the French archives. In all the family's historical documents that I inherited, the reality was the same: women were never mentioned. Even where the names of an individual's parents were to be included, I could only find the father's name. It was obvious to me how women were systematically made invisible in patriarchal societies, by authorities, religion and the family structure itself. I realized this invisibility is one of the historical reasons for all the inequalities women still face everyday. This awful reality awakens strong feelings of rebellion and discordance within myself. In order to challenge the historical disrespect and injustice against women, I decided to tell my story focusing on the feminine presence: the three 
important women in my life, my two mothers and my trans-sister, and the essential feminine influence in the creation of my own masculine identity. I realized how important women are in my life. I realized the power of their presence and their examples of dignity, courage, strength, beauty (the list goes on and on!) in my life.

From that moment on, my film evolved quickly: it went from being a quest about family history and memory to become a film in which the dignity, power and love of the feminine universe become the main role models for a gay man in search of his own masculine identity as he challenges the "established masculinity" models around him.

\section{Performance}

Inspired by such iconic, strong, dramatic characters such as the ones in Dumas fils' La Dame aux Camélias and Verdi's La Traviata, I started looking for equally strong elements that could support my story with originality, pertinence, and grace. I needed to find motifs and "supporting subjects" that could represent and depict with honesty the Brazilian, European, feminine and queer elements of my story.

Growing up in Brazil, in a religious catholic family, I was also under the influence of the spiritual and mystical contributions of the Indigenous and Afro-descending peoples to the Brazilian spirit and collective unconscious. In my household in Brazil, when the family was going through a difficult situation that required some sort of "divine intervention" (for lack of other solutions or simply by cultural habit), my very religious catholic family would not hesitate to use recipes and concoctions inherited from Brazilian Indigenous peoples, and seek for answers in religious rituals and/or practices inherited from our African descendants, the Black slaves, Gypsies, Jewish people etc. These "homemade remedies" and old practices are still used in 
Brazil and passed from one generation to the next by women. This is regarded as a "normal thing", and something that also helps defining what being a "true Brazilian" is all about.

The opening scene of A Magic Thread introduces an important subject that punctuates the rhythm of the whole film and represents this essentially mystical aspect of the Brazilian culture: Dagmar, a "Gypsy without a tribe", as she explains her own identity. The fact that Dagmar is a Brazilian woman and a "master of the Tarot cards" seemed to suit this need for a magic element in the film. From the beginning of the story, the audience sees a powerful, wise woman talking to me, giving directions, asking questions in order to start a process of reflection, self-reflection, discovery and wisdom, like one does in psychotherapy ${ }^{63}$ or as Socrates did in Greece as early as the $5^{\text {th }}$ century BC. ${ }^{64}$ The Gypsy and her cards represent the strength and mystery of the feminine elements as well as the path that leads to a "divine quest", to discovery and ultimately to selfknowledge. Her reading of the Tarot cards represents the steps one takes towards discovery, the passing of time, the cycles of life as well as a first performative element in the film. As she read the Tarot cards and interpreted them, she was aware that there would be more than one person in front of her: she knew that the film would have an audience and she performed her readings for me and also for my audience. Her voice and movements were pure performance. She was theatrically magical and she used that seduction power to make us believe in her reading of the cards. This way, she conveyed a certain truth. I believe this adds that magical and powerful

\footnotetext{
${ }^{63}$ Ian James, Rachel Morse, and Alan Howarth, "The Science and Art of Asking Questions in Cognitive Therapy," in Behavioural and Cognitive Psychotherapy, Vol. 38, Issue 1, January 2010, (Cambridge: Cambridge University Press), 83-93. https://www.cambridge.org/core/journals/behavioural-and-cognitivepsychotherapy/article/science-and-art-of-asking-questions-in-cognitive-therapy/ 29E7B0D99B0687C81783B4BC7595116B

${ }^{64}$ J.C. Overholser, "Elements of the Socratic Method: II. Inductive Reasoning" in Psychotherapy: Theory, Research, Practice, Training, Volume 30, Issue 1, Spring 1993, (American Psychological Association), 75-85. http://psycnet.apa.org/doiLanding?doi=10.1037\%2F0033-3204.30.1.75
} 
feminine touch. Following Stella Bruzzi's reasoning regarding performance in documentaries, I believe my choice to have the Gypsy in the film was successful because she intuitively understood that her performance in front of my camera was not expected to "simply represent the real", but the "dialectical conjunction of a real space and the filmmakers that invaded it". ${ }^{65}$

Although I was the only filmmaker in her presence, as I filmed the Gypsy's reading of the Tarot cards, the room was metaphorically filled with other filmmakers and individuals: the editors, the professors, the colour and sound professionals, the audience etc. Dagmar performed for all these people and for me.

I wished to reach a balance in the film. As a male subject, talking about my masculine feelings and ways of searching for some kind of truth, a historical or a personal one, I needed to balance this feminine performative aspect in my narrative with a masculine one. This became the dancer, with all the symbols that he represents in the story. Similar to the Gypsy, the dancer also performs in front of me and the audience. He introduces the element of sexual ambiguity in the film. He performs as the audience hears my telling of Felippe's story in Paris. On the one hand, he could represent Felippe, his youth, and his daring initiative of studying in Paris in the $19^{\text {th }}$ century, defying the authorities and the system by living with his courtesan lover. But the dancer also represents the "civilized and refined Parisian world" of ballet. Is there a more French symbol of elegance and refinement than le ballet with its arabesques, grands-écarts, allongés, battements tendus and so on? On the other hand, as a contrast with the "not so civilized and not so delicate" Brazilian environment, the dancer represents the feminine side of a masculine stereotype. He represents the queerness that permeates the whole film. The dancer challenges the

${ }^{65}$ Stella Bruzzi, New Documentary, (London and New York: Routledge, Taylor \& Francis Group, 2006), 152. 
patriarchal status quo by performing and offering beauty and grace that, in a macho-dominated country, is reserved only for women. The dancer offers an entry into the Jungian archetypes of anima and animus, the feminine presence in men and the masculine presence in women, and references the balance and beauty in life. ${ }^{66}$ Following a patriarchal mentality, he is all about women's "duties": being beautiful, delicate, fragile, weak and invisible. By introducing the male dancer with his "feminine-like qualities and abilities", his delicate movements, I intended to challenge patriarchy and pay yet another tribute to women.

I also did my very best to treat my father with as much respect as I approached the female subjects. For me, he represents the patriarchal mentality in Brazil. He obviously lacks this understanding and balance that Jung talks about when he explains the anima, the animus and their important role in our lives. By telling my father's story in my film, I realized I showed how embracing patriarchy and living according to traditional ideas without questioning them ultimately condemned my father to be a lonely man, a prisoner of his own decrepit notions and self-imposed harsh immediate living environment. Although we have a civil relationship as son and father, I know he will never question or try to change his own mentality. I don't believe he will ever watch my film and even if he did, he might choose to not understand it at all. He is 83 years old and I don't intend to challenge him at this age. This might sound like an easy solution, but I honestly believe he does not have the capacity to think about his values and try to change them. I believe he deserves the same level of respect as the other subjects in A Magic Thread. The solution for my ideological conflict with my father does not reside in him: it lives within myself. This is also a question of performance, an intimate one, between me and myself.

\footnotetext{
${ }^{66}$ Gary Toub, "Reflections on Psychology, Culture and Life," in The Jung Page, http:// www.cgjungpage.org/content/view/147/.
} 
Since my father represents patriarchy in my Brazilian universe, I consider this a performative role that I, as a filmmaker, attributed to him. This aspect of the performance becomes political. In the sequence of A Magic Thread where I discuss my own sexual orientation and my father's position vis-à-vis homosexuality, our points of view are opposed and we represent conflicting forces. I mention in my narration that I realized I was "different" from the time I was a child. I didn't know what that was all about, so I wasn't able to talk about it. I show then images of a homemade video from 1995 in which the audience sees me as a young gay man in an intimate moment, naked in bed with a boyfriend, in a depiction of same sex tenderness and sexual expression. This scene is accompanied by some text on the screen that explains it. Then the scene is followed by a contemporary reenactment of itself: the audience watches me in bed, in a similar situation of explicit and physical same sex tenderness. The next image is a still of my own father with a look of disapproval on his face, as if he were watching those scenes himself. I explain with my voice-over that my father said once, during a family meal, that he would rather have a criminal or a dead son than a "faggot" one. That statement shifts the subjects (myself as a filmmaker, my gay partners and my father) and those scenes into a political context. It embodies an additional challenge to patriarchy, according to which (and especially in Brazil) queer people could eventually be "tolerated" if they stay "hidden in their place," in some kind of confining closet. Queer people might be "tolerated" if they are not occupying spaces in society that patriarchal rules reserve for straight people. Gay men, for instance, will be "tolerated" in a patriarchal environment as hairdressers, make-up artists, couturiers, and in positions where they are "allowed to play" the role of the "flamboyant fag." I wished to address this kind of discrimination, prejudice and violence against queer people by creating the obvious contradiction 
between the explicit nude intimate gay scenes, the image of my father and his own statement regarding a possible "faggot" son. The subjects are not exactly themselves in this case, they "perform" and play the role of the queer resistance challenging the oppressive patriarchal system. 


\section{CONCLUSION}

From the moment I started conceiving A Magic Thread, and especially between the winter of 2016 and May 2017, my documentary went through a significant metamorphosis. So did I.

During this whole process, between conception of the film and the final stages of postproduction, I dealt with not only technical challenges, but personal ones as well: a health crisis, when I had to cope with contradictory medical diagnosis while also having to deal with the symptoms of illness, and a terrible loss in my family, my uncle Pedro, who was also one of the subjects in my film.

As I stated in my film, regarding my endless quest for the ideal model of a man to whom I could look up and of whom I could be proud, I understood I did not need to reproduce a traditional, binary scheme based in gender. I had in life so many magnificent models of humanity, be it all from women. The Universe put on my path many women as the magic thread of life.

Life and time have softened my father. Maturity helped me understanding he always acted as he was taught and according to the way he was raised. I realize he's done the best he could with the knowledge he had. He is the lonely, last survivor of his parents' children. He still lives in Monteiro in his parents' house, where he will certainly stay until the end of his life.

My trans-sister and I helped building each other's identity, even indirectly and unconsciously. She taught me resilience and courage. In situations where most men would have easily given up and surrender to despair, like our mothers, she stood firm, faced the storm and carried on with her feminine dignity. I want to believe I helped my sister realizing that some men are able to look at people and life through their learned feminine qualities: understanding, compassion, and love. 
Since documentaries are about unscripted real life and its "perennial movement" ${ }^{\prime \prime 6}$, I feel that my film and I evolved daily. A Magic Thread seemed to have a life and mind of its own. I embraced my human limitations and my role as a "conductor" who suggested and guided but, most importantly, who accepted the fact that I was not the ultimate decision maker in the process. The film, with its own narrative structure and needs, dictated most of these choices. As an aspiring filmmaker, I was doing nothing more than observing, listening and following instructions in my intuitive approach. However, I recognized, acknowledged and took responsibility for my decision-making process as a producer, director, cameraman, editor, and every other role I had to play. I took guidance from many other films, filmmakers and other sources.

A Magic Thread allowed me to superimpose my several narratives as one story as I expressed my redefined complex identity as a man, a brother, a son, a documentarian, an artist, and ultimately as a human being.

Word Count: 10,888 words

${ }^{67}$ This is the description of life that Dagmar Siqueira, one of Um Fio Mágico's main subjects, offers to the narrator. She is the self-proclaimed "gypsy without a tribe" whom I met when I was fourteen years old. 


\section{BIBLIOGRAPHY}

Arns, D. Paulo Evaristo, ed. Brasil: Nunca Mais - Um Relato para a História. Petrópolis, RJ: Editora Vozes, 1990.

Barroso, Gustavo. À Margem da História do Ceará. Fortaleza, CE: Imprensa Universitária do Ceará, 1962.

Bruce, Jean and Gerda Cammaer. Forbidden Love: A Queer Film Classic. Vancouver, BC: Arsenal Pulp Press, 2015.

Bruce, Jean. "Queer Cinema at the NFB: the 'Strange Case' of Forbidden Love" in Candid Eyes: Essays on Canadian Documentaries, edited by Jim Leach and Jeannette Sloniowski. Toronto: University of Toronto Press, 2003.

Bruzzi, Stella. New Documentary. London and New York: Routledge, Taylor \& Francis Group, 2006.

Buarque, Chico. "Não Existe Pecado ao Sul do Equador." Chico Canta. Comp. Ruy Guerra Chico Buarque, 1973.

Caruth, Cathy. "Recapturing the Past: Introduction" in Trauma: Explorations in Memory, 153. Baltimore and London: The John Hopkins University Press, 1995.

Citron, Michelle. "Fleeing from Documentary: Autobiographical Film/Video and the 'Ethics of Responsibility"' in Feminism and Documentary, edited by Diane Waldman and Janet Walker. Minneapolis and London: University of Minnesota Press, 1999.

de-la-Dehesa, Rafael. Queering the Public Sphere in Mexico and Brazil - Sexual Rights Movements in Emerging Democracies. Durham and London: Duke University Press, 2010.

Del-Priore, Mary. "As Mutações da Família Brasileira" in Aventuras na História, August 2014.

—. Histórias e Conversas de Mulher. São Paulo, SP: Planeta do Brasil, 2013.

Diffie, George D. Winius and Bailey W. Foundations of the Portuguese Empire - 1415-1580. Vol. 1, in Europe and the World in the Age of Expansion, edited by Boyd G. Shafer. Minneapolis: University of Minnesota Press, 1977.

Falcade, Ires Aparecida. "Capitalismo, Direitos Humanos e Encarceramento no Brasil" in II Congresso Internacional de Direitos Humanos e Políticas Públicas - Desigualdades e Intolerâncias em Tempos de Crise. Curitiba: Pontifícia Universidade Católica do Paraná, 2016. 
Freyre, Gilberto. Casa-Grande e Senzala. Lisboa: Livros do Brasil, 1957.

—. Sobrados e Mucambos. Rio de Janeiro, RJ: Editora Record, 1990.

Girardi, Neli Aparecida de Mello-Théry and Hervé Théry and Julio Hato and Eduardo Paulo. "Mapeamento do Trabalho Escravo Contemporâneo no Brasil: Dinâmicas Recentes" in Espaço e Economia - Revista Brasileira de Geografia Econômica, 2014.

Gordon, Richard A. "Recreating Caminha: the Earnest Adaptation of Brazil's Letter of Discovery in Humberto Mauro's "Descobrimento do Brasil" (1937)" in Hispanic Issue no. 2. Baltimore and London: The John Hopkins University Press, 2005.

Grant, Barry Keith and Jim Hillier. 100 Documentary Films - BFI Screen Guides. London: Palgrave Macmillan, 2009.

Grupo-Gay-da-Bahia. "Relatório 2016 - Assassinatos de LGBT no Brasil." Grupo Gay da Bahia, Salvador, 2016.

Guimarães, Antônio Sérgio Alfredo. Racismo e Anti-Racismo no Brasil. São Paulo, SP: Editora 34, 1999.

James, Ian, Rachel Morse and Alan Howart. "The Science and Art of Asking Questions in Cognitive Therapy." Behavioural and Cognitive Psychotherapy, January 2010.

Lissovsky, Maurício and Ana Lígia Leite e Aguiar. "The Brazilian Dictatorship and the Battle of Images." Sage Journals 8, no. 1, October 2014.

Macagnan-de-Souza, Janaína, Mário Estevam dos Santos Souza and William Alves dos Santos. "Direitos Humanos e Consciência Negra: Identificação da Cultura Afro-Brasileira na Sala de Aula." II Congresso Internacional de Direitos Humanos e Políticas Públicas Desigualdades e Intolerâncias em Tempos de Crise. Curitiba: Pontifícia Universidade Católica do Paraná, 2016.

Miglievich-Ribeiro, Adélia. "Darcy Ribeiro e o Enigma Brasil: um Exercício de Descolonização Epistemológica." Sociedade e Estado 26, no. 2, May/August 2011.

Mycofski, Carole A. "Bounded Identities: Women and Religion in Colonial Brazil, 1550-1750" edited by Taylor \& Francis Online. Religion 28, no. 4, 1998.

Overholser, J.C. "Elements of the Socratic Method: II. Inductive Reasoning." Psychotherapy: Theory, Research, Practice, Training, Spring 1993. 
Pastorello, Fabio. Viagens Cine. Fabio Pastorello. May 31, 2017.https:// viagenscinematograficas.com.br/2017/05/parada-do-orgulho-lgbt-sao-paulo.html.

Pereira, J. B. B. Religiosidade no Brasil. São Paulo, SP : Edusp, 2013.

Pieroni, Geraldo. Os Excluídos do Reino - A Inquisição Portuguesa e o Degredo para o Brasil Colônia. Brasília, DF: Editora Universidade de Brasília, 2000.

Pires, Maria Idalina. "Guerra dos Bárbaros - O Terrível Genocídio que a História não Conseguiu Esconder." In Dicionário de Datas da História do Brasil. São Paulo, SP: Editora Contexto, 2016.

Quem Disse. Quem Disse. 2017. https://quemdisse.com.br/frase/manda-quem-pode-obedecequem-tem-juizo/78782/.

Ribeiro, Darcy. O Povo Brasileiro: a Formação e o Sentido do Brasil. São Paulo, SP: Companhia das Letras, 1995.

—. "O Povo Brasileiro: Crítica ou Reforço à Noção de Caráter Nacional Brasileiro?" in Memória e Ciências Sociais by Alice Anabuki Plancherel, 161. Maceió, AL: Edufal, 2005.

Russell, Catherine. Experimental Ethnography: The Work of Film in the Age of Video. Durham and London: Duke University Press, 1999.

- Experimental Ethnography: The Work of Film in the Age of Video. Durham and London, NC: Duke University Press, 1999.

Sala-Molins, Louis, ed. Le Dictionnaire des Inquisiteurs (Valence, 1494). Paris: Galilée, 1981.

Souza, Jessé. "Gilberto Freyre e a Singularidade Cultural Brasileira." Tempo Social (SciELO) 12, no. 1, May 2000.

Toub, Gary. October 27, 2013. http://www.cgjungpage.org/content/view/147/.

Varda, Agnès. Les Glaneurs et la Glaneuse. Ciné-Tamaris: 2000.

—. Les Plages d'Agnès. Ciné-Tamaris and Arte France Cinéma: 2008.

Vezzali, Fabiana. "Especial Latifúndio - Concentração de Terra na Mão de Poucos Custa Caro ao Brasil." July 11, 2006.

Waugh, Thomas. The Right to Play Oneself: Looking Back on Documentary Film. Vol. 23. Minneapolis: University of Minnesota Press, 2011. 